\title{
Political Identities of Ukrainian Society in the Context of the EU Eastern Partnership Policy
}

\author{
Tożsamość polityczna społeczeństwa ukraińskiego \\ w kontekście polityki Partnerstwa Wschodniego
}

\begin{abstract}
The dynamics of European integration in Ukraine, defined by the Eastern Partnership Programme over the last decade, has attained many undeniable successes. Still, the current geopolitical situation leaves room for risks for both Ukraine and the entire community of European states. Faced with Russia's armed aggression, Ukraine is especially intent upon tackling the barriers of volatility, uncertainty, complexity, and ambiguity, which for years have been inherent in its foreign policy, and its choice of European identity. That having been said, the issue of political identity remains as urgent as ever, since taking account of the identifying features, and the study of the evolution and trends of the political identity of Ukrainian society paves the way for Ukraine's integration into the European political system.

Now, the identity of Ukrainians, which is still at the formative stage, can be described as partially ambivalent. In the meanwhile, a tendency towards acquiring the European system of values, in contrast to the Russian and Soviet ones, is being observed as well. Among the prevalent political identities that have emerged in Ukrainian societies under various historical, geopolitical, and cultural circumstances, two incompatibles yet competing groups - Western, represented by Ukrainian and European identities, and Eastern, represented by Russian and Soviet identities - can be discerned. In this regard, identities are not interpreted in terms of ethnicity but as politically constructible.

The article analyses Ukraine's European integration successes over the last years, which not only contributes to the upstream dynamics of European and Ukrainian identities but also prevents competitive identities from going forward. Today, the European foreign
\end{abstract}

1 Dr Olena DOBRZHANSKA, Institute of International Relations, Taras Shevchenko National University of Kyiv, e-mail: delil@meta.ua

2 Oleh PAVLIUK, undergraduate student, Institute of International Relations, Taras Shevchenko National University of Kyiv, e-mail: oleh_pavliuk@ukr.net 
policy course indisputably unites the Ukrainian nation, having a positive impact on its cooperation with the European Union in terms of politics, economy, and culture.

Keywords: geopolitics, Eastern Partnership, European integration, Ukraine, European Union, European values, identity, political identity, Ukrainian society, Ukrainian identity, European identity, Soviet identity, Russian identity

Abstrakt: Dynamika procesów integracji europejskiej na Ukrainie, które w ciagu ostatnich dziesięciu lat byly ukierunkowane programem Partnerstwa Wschodniego, ma swoje niezaprzeczalne sukcesy. Niemniej jednak w obecnej sytuacji geopolitycznej moga pojawić się zagrożenia zarówno dla Ukrainy, jak i całej Wspólnoty Europejskiej. W obliczu agresji wojskowej Federacji Rosyjskiej, Ukraina szczególnie dąży do przezwyciężenia barier niepewności, zmienności, złożoności i niejednoznaczności, które od zawsze towarzyszyły jej przy uprawianiu polityki zagranicznej i przy wyborze tożsamości europejskiej. W tym kontekście kwestia tożsamości politycznej pozostaje priorytetem, ponieważ uwzględnienie cech identyfikacyjnych, studium ewolucji i zrozumienie kierunków rozwoju tożsamości politycznej społeczeństwa ukraińskiego przyczynia się do spetnienia wymogów dotyczacych wejścia państwa ukraińskiego do europejskiego systemu politycznego.

Obecnie tożsamość Ukraińców, która jest wciqż w fazie kształtowania, charakteryzuje się pewna niejednoznacznością. Jednocześnie da się zaobserwować tendencje do dażenia do przyjęcia europejskiego systemu wartości jako przeciwwagi dla systemu rosyjskiego i radzieckiego. Wśród podstawowych tożsamości politycznych, które uksztattowaty się w społeczeństwie ukraińskim pod wpływem czynników historycznych, geopolitycznych $i$ kulturowych, wyróżniono dwie konkurencyjne i niekompatybilne grupy: Zachodnia ukraińska i europejska; Wschodnia - radziecka i rosyjska (w tym kontekście tożsamości nie sa traktowane jako etniczne, chodzi wytacznie o konstrukt polityczny.)

Wartykule przeanalizowano osiagnięcia Ukrainy w zakresie integracji europejskiej w ciagu ostatnich lat, które nie tylko pozytywnie wptywaja na dynamikę wzrostu tożsamości europejskiej i ukraińskiej, ale także zapobiegaja popularyzacji tożsamości konkurencyjnych. Kierunek europejski dzisiaj jednoznacznie sprzyja konsolidacji narodu ukrainskiego, co pozytywnie wplywa na rozwój wspótpracy z Unią Europejską w sferze politycznej, gospodarczej i kulturalnej.

Słowa kluczowe: geopolityka, Partnerstwo Wschodnie, integracja europejska, Ukraina, Unia Europejska, wartości europejskie, tożsamość, tożsamość polityczna, społeczeństwo ukraińskie, tożsamość ukrainska, tożsamość europejska, tożsamość radziecka, tożsamość rosyjska 


\section{Introduction}

The Eastern Partnership policy, which was originated by Poland and Sweden as far back as 2009, includes four pillars of cooperation: (1) Economic development and market opportunities; (2) Strengthening institutions and good governance; (3) Connectivity, energy efficiency, environment, and climate change; and (4) Mobility and people-to-people contacts. Within the Eastern Partnership framework, those pillars define cooperation between the European Union and six countries, namely Ukraine, Georgia, Moldova, Azerbaijan, Armenia, and Belarus (European Commission).

For Ukraine, it was a logical follow-up of years-long European integration processes in general, and a new impetus to cooperate with the European Union in particular. The first steps towards Ukrainian integration into European institutions were taken as far back as 1992. In 1998, a decree of the President of Ukraine entitled "On Approving the Strategy of Ukrainian Integration into European Union" set in motion tangible legal and regulatory changes to that effect (УказПрезидентаУкраїни).

Nevertheless, it is the Eastern Partnership framework that is associated with definitive European integration processes in Ukraine. It has been implemented via a number of means, including but not limited to:

- Erasmus+, a European Union programme, effective in Ukraine for the period 2014-2020, which underpins cooperation, partnership, events, and mobility in terms of education, vocational training, youth, and sports (ERASMUS+);

- The Deep and Comprehensive Free Trade Area (DCFTA) with the European Union, with effect as from 1 January 2016;

- The visa-free regime with the EU, which has been in operation since 11 June 2017. According to the Ukrinform national news agency, more than 2.5 million Ukrainians have already travelled to Europe on a visa-free basis (УНIА «Укрінформ»);

- Creating favourable conditions for Ukrainian citizens' mobility via opening the Ukrainian market to European passenger traffic companies;

- The coming into full force, as from 1 September 2017, of the EU-Ukraine Association Agreement (Свроінтеграційний портал);

- Amendments made on 7 February 2019 to the Constitution of Ukraine with regard to the strategic policy of attaining full-fledged membership in the European Union and North Atlantic Treaty Organisation (Законодавство України), in particular, (1) the preamble 
paragraph, after the words "civil harmony on Ukrainian soil", has been supplemented with the words "and affirming the European identity of the Ukrainian people and the irreversibility of the European and Euro-Atlantic policy of Ukraine," (2) paragraph 5 of part 1 of Article 85 has been amended as follows: "determining the principles of domestic and foreign policy, implementing the state strategic policy towards attaining full-fledged membership of Ukraine in the European Union and North Atlantic Treaty Organisation," (3) Article 102 has been supplemented as follows: "The President of Ukraine is the guarantor of the implementation of the state strategic policy towards attaining full-fledged membership of Ukraine in the European Union and North Atlantic Treaty Organisation," (4) Article 116 has been supplemented with paragraph 1-1, as follows: "ensures the implementation of the state strategic policy towards attaining full-fledged membership of Ukraine in the European Union and North Atlantic Treaty Organisation."

Still, despite the above sea-changes, debates concerning Ukraine's geopolitical choice are ongoing within the academia, in the political field, and even in everyday life. Ukraine's unique geographical location has carried over into its history, its struggle for independence, its search for reliable allies, and its endeavours to establish equal and amicable relations with its neighbours.

According to Samuel Huntington's clash of civilisations theory, Ukraine is located between two contradictory and permanently conflicting-either overtly or covertly - civilisations, which are impossible to reconcile by definition. In Huntington's opinion, the clash takes place on the border between the Greek Catholic (Western) and Orthodox (Eastern) Churches. Of similar view is Henry Kissinger, who considers Ukraine's geopolitical position to be a distribution of two global superpowers, namely Europe and Russia, the other four being the United States, China, Japan, and India.

That having been said, the West-East civilisational dichotomy is far too general and should rather be looked upon as two poles, with a broad spectrum of geocultural and geopolitical theories in between.

The Russian geopolitical concept of Eurasianism laid out in the works of the researcher Alexandr Dugin, puts Ukraine in an exclusively Russian imperial framework. "The existence of Ukraine as a sovereign nation is tantamount to dealing a severe blow to Russia's geopolitical security and tantamount to invasion into its territory" (Дугин 2000). 
By and large, all current Western European, Russian and Ukrainian schools of geopolitical thought tend to concur in an understanding of civilisational differences and tendencies of conflict escalation. Still, they differ significantly in how they assess facts, expose cause-and-effect relationships, set out their terminology and classification, and, last but not least, in determining the geopolitical vector and the prospects of Ukraine's existence as a sovereign state.

For Ukrainian society, this choice reflects the peculiarities of the historical development of Ukraine's geopolitical location as a civilisational border between West and East. Whereas scientists and political and economic elites are focused on multi-criteria approaches, Ukrainian laypeople's choice of political identity narrows down to opting for two antagonistic civilisations and identities. Nowadays, the issue of the identity of Ukrainian society takes on greater significance in terms of understanding the prospects of Ukraine's European integration and the course of foreign policy.

The study in the psychology of identity-induced behaviour, value orientation, and decision-making on both levels, individual and collective, began as far back as the early 20th century. Whereas the German-American psychologist Erik Erikson studied the mechanisms of acquiring collective identities through personality formation, the German psychoanalyst Erich Fromm recognised individual identity as a result of individualisation, and thought social identity to be depersonalisation. There are separate studies dedicated to singling out and analysing people's collective and individual identities as well. In this regard, the self-concept of the personality within the social identity theory by the British psychologist Henri Tajfel stands out, as it investigates the reasons behind the tension and its determinants in intergroup conflicts.

One's individual identity and numerous collective identities simultaneously affect a person engaged in social contact. Here, two levels of conflict - internal and external - can be differentiated, which are related to the person's problems and their interactions with people belonging to different collective identities. A person's internal conflict can be rooted, among other reasons, in the fact of assuming a new collective identity. Such conflict takes on a particularly acute turn in cases when a new identity is assumed not through natural age-related changes, which were thoroughly investigated by Erikson (Erikson 1968: 336), but by virtue of historical and social impact upon a mature personality, which force it to give up its former identity in favour of a new one. 
The system of collective identities is complex and multifaceted, with differing identities interacting with each other. One identity can be both a prerequisite for and a threat to another, which makes it possible to distinguish between independent/dependent, compatible/incompatible, alternative/competing, short-term/long-term, strong/weak, temporary/ permanent, positive/negative, etc. identities. This is, of course, a non-exhaustive list of possible criteria for identity classification; to take an example, Erikson suggested four identity types (Эриксон 1996: 592): (1) identity diffusion, where no definite choice for identity has been made yet, (2) identity foreclosure, with the said choice being made in conformity with commonplace standards or expectations rather than of one's own volition, (3) identity moratorium, where readiness to choose a particular identity is not translated into a definitive commitment thereto, and (4) identity achievement, with a commitment to a particular identity already made, which leads to practical self-realisation.

A person's collective identities are structured within a particular hierarchy that reflects significant identifications, with such hierarchies and identity, overlaps varying from one group of people to another. Whereas a person's collective identities are not necessarily conflicting, their individual identity and any given collective identity are fundamentally incompatible, with the former seeking to separate and the latter designed to prevent any separation from a particular social group. This constitutes another reason for a personality's internal conflict, which might exacerbate in the case of choice between one's self-interest and group interest.

As per external conflict, i.e. one that comes up between a person and a group, it may have both objective and subjective reasons behind it. From the personality's standpoint, the us-them opposition comes about as identity itself is shaped, since one's self-identification is understood, it inevitably entails an understanding of one's differentiation from the others. Tajfel coined the term "ingroup favouritism" for this desire to engage in positive groups. With external factors pushing one towards competition, conflict becomes imminent, the difference being in its manifestations and forms of opposition.

In modern political science, constructivist approaches to identity tend to regard it as a phenomenon able to explain the behaviours of a person, society, and the state. There is ample scientific literature to that end, including the recent book by the prominent American thinker Francis Fukuyama entitled Identity: The Demand for Dignity and the Politics of Resentment, in which 
he reinvigorates the term "identity politics" to explain current geopolitical and internal political transformations. It "encompasses a large part of the political struggles of the contemporary world, from democratic revolutions to new social movements, from nationalism and Islamism to the politics on contemporary American university campuses" (Fukuyama 2018: 10).

The global transition to democracy has enabled people to choose their respective governments, whereas the advent of information and communication technologies has engendered new forms of social needs and means to see to their fulfilment. Over the last 40 years, the number of voting democracies in the world has grown from 35 to more than 110 (Fukuyama).

Where party identity is lacking, citizens choose their government by drawing upon a wider concept of political identity. Ukrainian society lacks long-term party identity, while the prevailing political identities can be divided into two competing and incompatible groups: (1) Western-Ukrainian and European identities, and (2) Eastern-Soviet and Russian identities. It should be noted that, in this particular meaning, the said identities are not regarded as ethnic but merely political constructs. Bearers of those identities stand up for a particular form of government, public order, political culture, civil society, the account of history, their role in statecraft, and Ukraine's future.

In order to understand the successes of European integration, as well as the reasons behind their understatement, the four political identities need to be analysed, with due attention being paid to classification, rating, the motivation behind the choice of a particular identity, identification mechanisms, self-description, identities' impact upon the politics, and their interplay in Ukrainian society.

Among Ukrainian citizens, Ukraine's identity, which asserts that Ukraine is an independent, sovereign, and democratic European state, is indisputably prevalent. Ukrainian identity is acquired and shaped in a way that resembles the Western national identity concept suggested by Anthony Smith, the British researcher of nationalism and nations. This concept defines the following key features of national identity: (1) a common historic territory, (2) common laws and institutions, (3) political equality of citizens through a system of rights and duties, and (4) a common civic culture and ideology (Сміт 1994: 19).

It would be too soon now to speak of a definite Ukrainian identity; it continues to shape itself, and it tends to manifest ambiguity along the way. It is marred by notable regional, social, ideological differences rooted 
in historical and cultural backgrounds, which affects its integrity. Still, a strong positive proclivity towards the strengthening of Ukrainian identity has been observed over the years of Ukraine's independence, which is backed by opinion polling.

In the 1991 referendum, 84.18\% of Ukrainian citizens took part, with 90.32\% voting in favour of Ukraine's independence (Андрощук).

A 2007 public opinion poll by the Razumkov Centre revealed that $57.9 \%$ of Ukrainians identify themselves with the Ukrainian cultural tradition; $19.4 \%$, with the Soviet one; $10.1 \%$, with the Russian one; and 6,4\%, with the European one. Also, 33.8\% of those interviewed said that they felt European, with $11.9 \%$ saying "definitely" and 21.9\% saying "probably" (Razumkov Centre 2007). In a 2016 Razumkov Centre research, it was found that $86 \%$ of Ukrainian citizens said that they believed themselves to be Ukrainians; $11 \%$, Russians, $2 \%$ giving a different answer, and 1\% undecided (Razumkov Centre 2016). A 2017 Razumkov Centre opinion poll indicated that $92 \%$ of those interviewed defined their ethnicity as Ukrainian, and $6 \%$ as Russian, whereas $1.5 \%$ gave a different answer, and $0.6 \%$ were undecided (Razumkov Centre 2017).

A 2018 research by the IlkoKucheriv Democratic Initiatives Foundation and the Kyiv International Institute of Sociology showed that $44 \%$ of Ukrainians regarded themselves as European, with 15\% saying "definitely" and 29\% saying "probably". On a regional level, this included $61 \%$ in the west, $51 \%$ in the centre, $28 \%$ in the south, and $22 \%$ in the east of Ukraine (The Ilko Kucheriv Democratic Initiatives Foundation - Dif).

Although, since 2014, the researches have been conducted only in Ukrainian government-controlled territories and do not reflect the opinion of people in Russia-annexed Crimea and the particular areas of the Donetsk and Luhansk region, there is an evident and strong tendency towards an increase in the number of Ukrainian and European identity's bearers. Further to this, the 2019 presidential election in Ukraine was widely regarded as having all the indications of a voting democracy, and in the 2019 parliamentary by-election, four out of the five parties that ended up in office pledged to defend Ukraine's state sovereignty and support Ukraine's foreign European policy. This adds to the tendency towards accepting the European system of values and is a solid proof of Ukrainian citizens' demand put forward to the authorities. Further implementation of the standards of European democracy is becoming an important component in Ukraine's public life and a test of its government's legitimacy. 
For post-Soviet countries undergoing active democratic transformation, the European Union has been the leading model of liberal democracy. Even in the face of the global economic crisis, Brexit, and other threats that the European Union has faced, European identity retains the status of a positive group for the overwhelming majority of Ukrainian society (Governmental Portal 2019).

European identity, which is only taking root in Ukrainian society, is among the major political identities demonstrating an active growth dynamic. For Ukrainians, however, its content is not tantamount to the European identity, as seen in the European Union countries.

The history of a common Europe has been complex and ambiguous, and European borders have been defined differently throughout history. Various researches of the processes of European integration have been carried out within the frameworks of the traditional theory of federalism, functionalism, neo-functionalism, modernized neo-functionalism, and constructivism, which have studied the influence of economic, political and cultural factors on the prospects and forms of a united Europe.

Having ended with territorial expansion, the European Union as an economic and political union of independent states created and gradually expanded its geographical territory, with priority being given to liberal values, democratic procedures and institutions, and the terms "European values" and "European identity" have been reflected both in the minds of its citizens and in relevant statutes.

Long-term historical processes have shaped the cultural idea of Europe and have transformed it into a political identity with cut-and-dried identification tools within the borders of the modern European Union. A 2018 survey by the European Commission opinion polling service Eurobarometer showed that $73 \%$ of people in the European Union recognised their European citizenship (Standard Eurobarometer 2019). Still, the vast majority of Poles, Germans, French, and other EU member states' citizens did not identify themselves as Europeans beyond the national definition. This finding is in line with the overall result of Eurobarometer surveys over the past decade: more than half of Europeans recognise themselves as EU citizens while retaining their national identity as their top priority. And the number of citizens who have given up on their national identity in favour of exclusive European identity varies between $0 \%$ and $8 \%$ from country to country. This indicates that there is no forced transition from national to supranational loyalty of citizens within the EU, debunking the 
claim that a single political idea threatens national identity and sovereignty of EU member states.

It is clearly too soon to speak of homogeneous identity in 28 EU countries among 513 million people of various cultural and ethnic backgrounds. On the whole, however, there is every reason to recognise a stable European identity of the EU member states, which continues to assert itself as a successful political construct (Eurostat 2019).

The issue of whether Ukraine is to be recognised as part of the cultural and geographical space of Europe and whether Ukrainian society shares European identity is a moot point, further complicated by the lack of a common geopolitical strategy of the EU member states concerning Ukraine. The irony of such political thinking is that, on the one hand, Ukraine is still thought to belong in the post-Soviet group of countries, whereas on the other hand, the countries of the former Soviet bloc have long been an integral part of Central and Eastern Europe.

Ukrainian society started actively identifying itself as European in 2013, which escalated into the Revolution of Dignity, its price is the violation of Ukraine's territorial integrity and the death toll of more than 13,000 in the east of Ukraine (Радіо Свобода). European collective identity, though, cannot be built solely upon self-identification, without the recognition by the European community of Ukrainians as its integral component. Otherwise, Ukraine will end up in a state of identity foreclosure.

In this regard, the Eastern Partnership policy is a clear step forward compared to the European Neighbourhood Policy (ENP), which has, since May 2004, included 16 different countries (Ukraine, Moldova, Belarus, Georgia, Armenia, Azerbaijan, Algeria, Egypt, Israel, Jordan, Lebanon, Libya, Morocco, Syria, Tunisia, the Palestinian Authority) (European Neighbourhood Policy). Still, the question "What do the selected countries have in common?" has not lost its relevance concerning the Eastern Partnership programme as well. At the present stage, it should be recognised that there are no common values upon which the Eastern Partnership policy can be based and that there is a clear divide between the concerned countries into two distinct groups. The significant advancement in terms of European integration by Ukraine, Georgia, and Moldova cannot be replicated, even in theory, by Azerbaijan, Armenia, or Belarus because of other commitments arising from their membership in the Eurasian Economic Union or the Collective Security Treaty Organisation (CSTO, or the Tashkent Treaty). 
Two out of the six countries concerned, namely Georgia (2009) and Ukraine (2018), have withdrawn from the Commonwealth of Independent States (CIS) due to Russian armed aggression. The other countries retain CIS membership, which by definition makes them subject to the political and economic influence of the Russian Federation. In addition, there is a number of apparent differences between the participating states in terms of the implementation of European values of democracy, freedom of speech, etc., which renders the discourse on a common European identity irrelevant.

In order to establish a positive model of European identity, Ukraine needs to understand its relationship with Europe, either a member of the European community or simply its eastern neighbour. It is on this understanding that the image of European identity in Ukrainian society is being shaped, which has two specific dimensions-economic and cultural.

The stereotype of "European economic standard", which was commonplace in Ukrainian society as far back as during consumers' scarcities in the Soviet Union, still affects the public mood. A number of opinion polls confirm that the poor financial and social status of some strata of Ukrainian society leads to a rejection of European identity. At the same time, the high financial and social status do not necessitate one's European self-identification. This leads to the conclusion that the purely material dimension of European identity is a certain criterion in shaping the image of "them" among those not belonging in this group.

In turn, the cultural dimension of Europe's image among Ukrainians has embraced all the ideals of Western society-peace, democracy, security and stability, the rule of law and equality before the law, civil liberties, human rights, non-discrimination, freedom of personality and self-realisation, etc. The European vector of Ukraine's development is, therefore, seen as a key to their fulfilment. It is clear that such an image is idealised, and long-cherished change in Ukraine requires some effort and political will, mostly from the Ukrainians themselves.

The existing system of international relations leaves no room for "multi-vector foreign policy" and the diffusion of a country's identity through its foreign policy; Ukraine's return to those strategies runs the risk of the country losing its independence. The civilisational choice by Ukraine of its future path becomes inevitable.

Given the ongoing armed and information aggression of the Russian Federation, which has been threatening Ukraine as a sovereign state for 
five years and is designed to humiliate, oppress, or even deny the existence and subsequently destroy Ukrainian identity, European self-identification is also looked upon as a possible safeguard of Ukrainian identity.

Instead, the doubtful nature of Ukrainians' self-perception as Europeans, fomented by Russian propaganda, creates favourable conditions for the development of alternative and competing identities, such as the Soviet and Russian ones.

An example of identity foreclosure under Erikson's identity classification, Soviet identity, which was formed within the Soviet compulsory programme of socialisation, fosters a sense of unity with a long-standing non-existent community.

Formed artificially, Soviet identity is indicative of sustainability and durability. Its bearers are mostly older people, who today are not necessarily Marxists or communists by ideology but, as a rule, citizens who have not found a positive identity in the new post-Soviet environment, where the Soviet ideals they acquired ran counter to the growing national consciousness of a new Ukraine. Although its proponents are declining due to natural demographic factors, Soviet identity continues to influence the political preferences of a part of the Ukrainian population.

When it took part in elections, the Communist Party of Ukraine always reached the electoral threshold, and although its support dynamic was fast declining, the bearers of Soviet identity made up its core base. In 1994, the Communist Party had the largest faction in the Verkhovna Rada; in 1998, it was voted for by $24.65 \%$ of Ukrainians; in 2002 , by $19.98 \%$; in 2006 , by $3.66 \%$; in 2007 , by $5.39 \%$; in 2012 , by $13.18 \%$; and in 2014, by $3.88 \%$ (Central Electoral Commission). It is understood that not all those with Soviet collective identity voted exclusively for the Communist Party, for there were other alternatives. Nevertheless, they never supported parties that would run on Ukrainian nationalist or Western European platforms.

For Western European countries, communism was a hostile ideology since the bipolar world emerged, and the countries of Eastern Europe that were part of the Soviet bloc have taken action in terms of decommunization and criminal liability for propagating communist ideology. Since 2015, Ukraine has also taken decommunization measures and adopted the Law "On Condemning the Communist and National Socialist (Nazi) Totalitarian Regimes in Ukraine and Prohibiting the Propaganda of Their Symbols." (Закон). 
Instead, since 2000, the Russian Federation has gradually reverted to the propaganda of Soviet symbols, victories, and heroes, effectively applying the Chinese stratagem of "borrowing a corpse to resurrect the soul," and thereby securing the trust and respect of the bearers of Soviet identity in the entire post-Soviet world.

Although the opinions of the bearers of Soviet and Russian political identities nearly coincide as of now, these identities are not homogeneous and have significant differences. In Ukrainian society, Russian political identity unites people who support the view that "one of the topical geopolitical demands of Russia is the rebuilding of the Empire," and "the battle for global domination of the Russians is not over" (Дугин 2000).

Apart from identification with "Greater Russia" and "the Russian world" and denying Ukrainian statehood, the indispensable feature of Russian identity is the Russian language-as well as utter intolerance to the Ukrainian language. However, notwithstanding the exploitation of the language issue by pro-Russian political groups in Ukraine, those Ukrainians that continue to speak Russian in interpersonal communication do not form a homogeneous group. According to a 2019 survey by the Kyiv International Institute of Sociology, "28.1\% of Ukrainians speak mostly or only Russian, with $15.8 \%$ speaking only Russian. Another $24.9 \%$ of Ukrainians speak Ukrainian and Russian equally" (Київськийміжнарод нийінститутсоціології). Comparing these figures with the results of the voting in the 2019 Ukrainian parliamentary election leads to the conclusion that the number of Russian-speaking population in Ukraine is much higher than the number of supporters of pro-Russian parties. Only one pro-Russian party, Opposition Platform - For Life, passed this year's election threshold and was voted for by $13.05 \%$ of Ukrainians, or 1,908,111 citizens. A total of $14,749,867$ Ukrainians took part in the parliamentary elections (Центральнавиборчакомісія). These figures do play into the assertion of Western identities among Ukrainian citizens, as opposed to Eastern ones. Such transformation is due to the current successes of European integration projects, including the implementation of the Eastern Partnership policy with the European Union. 


\section{Conclusions}

The European self-identification of Ukraine is confirmed by the achievements of the implementation of the Eastern Partnership programme with the EU, which over the last five years has acquired the most active dynamics, and proved the irreversibility of the European integration processes. Such self-identification, though, is not sufficient for Ukrainian society to achieve European collective identity. For today's Ukraine, it is critical to understand its role and place in the European community as an integral part of European identity.

The affirmation of a positive European identity, in turn, strengthens Ukrainian identity and prevents an increase - and, in some cases, promotes a reduction - in the number of proponents of Eastern political identity (Soviet and Russian ones), who do not support European integration initiatives. At the present stage, opinion polls and election results in Ukraine show an increase in the number of proponents of Western types of political identities, which contributes to the democratization of all spheres of Ukrainian society and adds to the legitimacy of European integration processes. Should they gain traction, those trends will further contribute to the European Union's intentions to have a stable, benevolent, and reliable partner with a predictable and friendly foreign policy on its eastern border.

Depending on the successes in the implementation of the Eastern Partnership programme with the EU, the participating countries have ended up divided into two groups, the first being the countries that have exhibited landmark transformations in the course of European integration processes - Ukraine, Georgia, and Moldova; and the second group including countries that over the last decades have directed their foreign policy vector to an openly pro-Russian orientation, are unable to implement most European initiatives due to other international commitments, or neglect the core values of Western European democracy - Azerbaijan, Armenia, Belarus. This imbalance impedes the strategic vision of the further development of the Eastern Partnership project in the old format and requires, at the very least, that two separate programmes be initiated, each bringing together countries depending on the key results and the relevance of those results to the expectations of the European Commission. 


\section{References}

Андрощук, О.В., 'Референдум першого грудня 1991', Енииклопедія історії України, http:/ / www.history.org.ua/?termin=Referendum (17.03.2020).

Центральна виборча комісія, Вибори народних депутатів Украӥни, https:// www.cvk.gov.ua/vibory_category/vibori-narodnih-deputativ-ukraini.html (17.03.2020).

Центральна виборча комісія, Позачергові вибори народних депутатів Украйни 21 ıипня 2019 року, https:/ / www.cvk.gov.ua/wp-content/uploads/2019/09/ protokol_zbvo_03082019.pdf (17.03.2020).

Сміт, Е. (1994) Національна ідентичність, пер. з англ. Основи, (Київ): 19.

Дугин, А. (2000), Основы геополитики, Артогея, Москва, http:/ / arctogaia.com/ public/osnovygeo/geop12.htm.

ERASMUS+, Національний Еразмус+ офріс в Україні, Про програму Європейського Союзy - ERASMUS+, https://erasmusplus.org.ua/erasmus/pro-prohramu.html (05.10.2019).

Эриксон, Э. (1996), Детство и общество, пер. с англ., Ленато, АСТ, Фонд, Университетская книга, (Санкт-Петербург): 592.

Свроінтеграційний портал, Угода про асоціацію між Україною та ЄC, https:/ / eu-ua.org/tekst-uhody-pro-asotsiatsiiu (25.09.2017).

European Commission, European Neighbourhood Policy and Enlargement Negotiations, https:/ / ec.europa.eu/neighbourhood-enlargement/neighbourhood/easternpartnership_en (05.10.2019).

European Neighbourhood Policy (ENP), https:/ / eeas.europa.eu/diplomatic-network/ european-neighbourhood-policy-enp/330/european-neighbourhood-policy-enp_ en (21.12.2016).

The Ilko Kucheriv Democratic Initiatives Foundation (Dif), Фонд «Демократичні ініціативи» імені Ілька Кучеріва, Європейська інтеграція у вимірі громадської думки, https:/ / dif.org.ua/article/evropeyska-integratsiya-u-vimirigromadskoi-dumki (28.09.2018).

Fukuyama, F., Against Identity Politics, https://www.sas.upenn.edu/andreamitchell-center/francis-fukuyama-against-identity-politics (05.10.2019).

Fukuyama, F. (2018), Identity: The Demand for Dignity and the Politics of Resentment, Farrar, Straus and Giroux: 10.

Київський міжнародний інститут соціології, Думки $і$ погляди населення щодо викладання російської мови в українськомовних школах і надання непідконтрольним територіям Донбасу автономії у складі Украйни: Березень 2019 року, http:/ / www.kiis.com.ua/ ?lang=ukr\&cat=reports\&id=832\&page=1 (15.03.2019).

Радіо Свобода, 13 тисяч: офіційні дані ООН щодо загиблих у війні на Донбасі, https:/ / www.radiosvoboda.org/a/29792144.html (26.02.2019). 
Razumkov Centre (2017), Основні засади та шляхи фрормування спільної ідентичності громадян України, Національна безпека і оборона, 1-2: 169-170, http:/ / razumkov.org.ua/uploads/journal/ukr/NSD169-170_2017_ukr.pdf (05.10.2019).

Razumkov Centre (2016), Консолідація українського суспільства: виклики, можливості, шляхи, Національна безпека і оборона, 7-8: 165-166, http:/ / razumkov. org.ua/uploads/journal/ukr/NSD165-166_2016_ukr.pdf (05.10.2019).

Razumkov Centre (2007), ‘Формування спільної ідентичності громадян України: перспективи і виклики', Національна безпека і оборона, 93(9), http:/ / razumkov.org.ua/uploads/journal/ukr/NSD93_2007_ukr.pdf (05.10.2019).

Результати всеукрайнських соціологічних досліджень щодо ставлення громадськості до інтеграції України до ЄC, https://www.kmu.gov.ua/news/72ukrayinciv-potrebuyut-bilshe-informaciyi-pro-yes-ta-yevrointegraciyu-52pro-nato (09.07.2019).

Standard Eurobarometer (2019), Public opinion in the European Union: First Results, 91, Spring, http://hr.n1info.com/Binary/257/Eurobarometar-proljece-2019. pdf (05.10.2019).

Указ Президента України, Про затвердження Стратегії інтеграції Украйни до Європейського Союзу, від 11 червня 1998 року 615/98, https://zakon.rada. gov.ua/laws/show/615/98 (17.03.2020).

УНІА «Укрінформ», Цього дня два роки тому набув чинності безвіз з ЄС, https:/ / www.ukrinform.ua/rubric-society / 2718677-cogo-dna-dva-rokitomu-nabuv-cinnosti-bezviz-z-es.html (11.06.2019).

Закон, Про засудження комуністичного та націонал-соціалістичного (нацистського) тоталітарних режимів в Україні та заборону пропаганди їхньої символіки, https://zakon.rada.gov.ua/laws/show/317-19 (17.03.2020).

Законодавство України: Конституція України, https://zakon.rada.gov.ua/ laws/main/254\%D0\%BA/96-\%D0\%B2\%D1\%80 (21.02.2019). 